\title{
欠陥を有するトンネル覆工の変形挙動と 内面補強工の效果
}

\author{
朝倉俊弘* ・安東豊弘 ${ }^{* *}$ ・小俣富士夫*** \\ 若菜和之 ${ }^{* * *} \cdot$ 松浦章夫 $* * * * *$
}

従来のトンネル工法で施工されたトンネルの覆工は, 施工上の理由から, 天端部の巻 厚不足と背面空洞の存在という構造的欠陥を有することが多い.このような欠陥が覆工 の力学挙動に与える影響と, 裏込注入工及び鋼板接着・炭素繊維シート接着による内面 補強工の効果を模型実験と骨組解析により検討した。

Key Words : tunnel lining, tunnel model test, frame analysis, backfill grouting, inner reinforcement

\section{1.はじめに}

老朽化したトンネル, あるいは供用開始後, 土圧の作 用により変状の生じたトンネルは少なくない.

しかしながら，そのような変状トンネル覆工の対策工 を設計しようとする際, あるいは近年急増している既設 トンネルに対する近接工事を計画する場合の影響評価の 際, トンネル覆工の健全度, すなわち応力状態を判断す る定量的手段がないため，的確な設計に支障をきたす場 合が少なくない.

また，トンネル覆工には，コンクリート打設時の硬化 収縮や地圧作用によるひび割れが若干なりとも生じてい ることが一般的であり，さらに，鋼製支保工と木矢板に よる, いわゆる在来工法によるトンネルでは, コンクリー ト打設技術に起因してアーチクラウン部に巻厚不足や背 面空洞が存在することが一般的である.このような構造 的欠陥が, 覆工の健全度評価をさらに困難なものとして いる.

本研究は, トンネル覆工の力学的な健全度評価法の確 立と, 変状対策工の設計基準を作成することを最終目的 としているが, 本論文では, 特に上述したような巻厚不 足, 背面空洞といった構造的欠陥が, 覆工の変形挙動特 性に与える影響を把握することと, 裏込注入, 内面補強 工といった変状対策工の効果を把握することを目的とし ている.

本論文では，構造的欠陥を有するトンネル覆工の挙動

\footnotetext{
*正会員工修 (財)鉄道総合技術研究所 トンネル研究 室 主任研究員

（１85 東京都国分寺市光町 2-8-38）

**正会員 東日本旅客鉄道(株) 秋田支社 工務部施設課 主席

***正会員 ショーボンド建設(株) 土木研究所 課長

****正会員 工修 ショーボンド建設(株) 土木研究所 研 究員

***** 正会員 工博 金沢工業大学教授 土木工学科
}

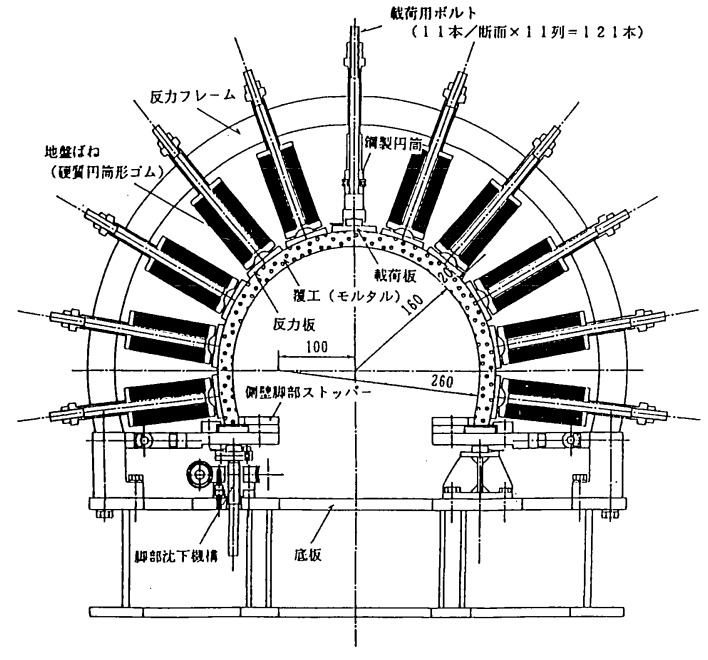

図一1＼cjkstart実験装置の概要（断面図）

と変状対策工の効果に関する模型実験結果, 実験結果の 骨組解析によるシミュレーション, 若干のパラメトリッ ク解析結果，および得られた知見について報告する.

\section{2. 模型実験}

\section{（1）実験装置}

実験装置は, 図一1に示すように，新幹線複線トンネ ル標準断面を想定した直接載荷方式の模型実験装置（縮 尺 $1 / 30)^{11,2)}$ で, 載荷用部材 (載荷板, 反力板, 地盤ば ね材 (硬質円筒形ゴム), 二重ねじ構造の載荷用ボルト 等), 反カフレーム, 側壁脚部ストッパー, 脚部沈下機構, 底板等により構成されている。

載荷用部材は覆工供試体（以下，供試体と呼ぶ.）を 取り冊むように，供試体断面の法線方向に 11 本設置さ れている. 載荷用ボルトは二重ねじ構造になっており, 内側のボルトにより円筒形ゴムの圧縮, 解放を行うこと 
表一1 実験ケース

\begin{tabular}{|c|c|c|c|c|c|c|}
\hline $\begin{array}{l}\text { 奏一験 } \\
\text { 番一䂞 }\end{array}$ & $\begin{array}{l}\text { 载 荷 } \\
\text { 位 置 }\end{array}$ &  & $\begin{array}{l}\text { 背 面 } \\
\text { 空 洞 }\end{array}$ & $\begin{array}{l}\text { 裹 } \\
\text { 注 }\end{array}$ & $\begin{array}{l}\text { 内 面 } \\
\text { 補 強 }\end{array}$ &  \\
\hline 1 & \multirow{3}{*}{$\begin{array}{c}\text { 鉛 直 } \\
\text { [6] }\end{array}$} & \multirow{3}{*}{$20 \mathrm{~mm}$} & \multirow{3}{*}{ 無 } & \multirow{3}{*}{ 無 } & 無 & 健 全 \\
\hline 2 & & & & & 鎆 板 & \multirow{2}{*}{ 対策工 } \\
\hline 3 & & & & & 炭素䋐維 & \\
\hline 4 & \multirow{6}{*}{$\begin{array}{l}\text { 横両側 } \\
\text { [(2)(10] }\end{array}$} & $20 \mathrm{~mm}$ & 無 & \multirow{4}{*}{ 無 } & \multirow{6}{*}{ 無 } & 健 全 \\
\hline 5 & & $10 \mathrm{~mm}$ & $60^{\circ}$ & & & \\
\hline 6 & & $15 \mathrm{~mm}$ & & & & 欠 陥 \\
\hline 7 & & \multirow{3}{*}{$10 \mathrm{~mm}$} & $100^{\circ}$ & & & \\
\hline 8 & & & \multirow{2}{*}{$60^{\circ}$} & 軟質材 & & \multirow{2}{*}{ 対策工 } \\
\hline 9 & & & & 硬質材 & & \\
\hline
\end{tabular}

注）載荷位置の [] 内の数字は載荷板番号を示す。(下図参照)

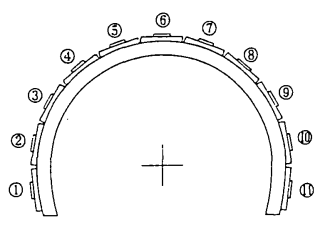

が可能で, ゴムの弾性力により地盤反力を表現している. 載荷箇所は，円筒形ゴムを鋼製の中空円筒に交換し，外 側のボルトを礼じ込むことにより載荷板を介して供試体 に直接変位を与える。また，載荷用部材は供試体の軸方 向にも 11 列並んでおり（装置全体では，11個／断面× 11 列=121 個), 3 次元モデルの実験も行える構造となっ ていることが大きな特徵である.

側壁脚部は，鋼製またはゴム製の脚部ストッパーを着 脱することにより，インバートの有無，道床砕石等によ る支持などの水平内側拘束条件を設定できる構造となっ ている.

また，脚部沈下機構を備えており，既設トンネルの下 部に新設トンネルが通過する場合などの脚部沈下を模擬 した実験も行うことができる.

\section{(2) 実験概要}

\section{a) 実験ケース}

覆工欠陥 (天端巻厚不足), 天端背面空洞, 変状対策 工 (裏込注入工, 鋼板接着, 炭素繊維シート補強) の有 無をパラメータとして, 表一1に示す 9 ケースについて, トンネル軸方向に載荷板 1 枚分の長さ $(L=60 \mathrm{~mm})$ を 持つ 2 次元モデルを用いて実施した.

なお，今回の実験は打継ぎのない順巻モデルで，イン バートがある場合を想定して行っている.

また，荷重については，ケース 1〜3 はトンネル施工 後のゆるみ進行による鉛直地圧を，ケース 4 〜 はトン ネル周辺地山が塑性化した場合で卓越した側圧を，それ ぞれイメージして決定した。

b) 実験材料

供試体はセメントモルタルにて作製し,地盤ばね材は, 覆工の変形挙動を強調する目的で，沖積層程度に相当す
表一2 実験材料の諸物性

\begin{tabular}{|c|c|c|}
\hline 別 & 実験使用材料 & 材 料 物 性 \\
\hline $\begin{array}{l}\text { 覆 } \text { 工 } \\
\text { 模 } \\
\text { 型 }\end{array}$ & モルタル & $\begin{array}{ll}\text { 一軸圧縮強度 } & \sigma \mathrm{c}=31 \mathrm{MPa} \\
\text { 压縮弾性係数 } & \mathrm{Ec}=1.6 \times 10^{4} \mathrm{MPa}\end{array}$ \\
\hline 地盤ばね材 & 硬質円筒形ゴム & $\begin{array}{l}\text { ばね定数 } \quad \mathrm{K}_{1}=0.080 \mathrm{kN} / \mathrm{mm} \\
\text { (変位量 } 4.0 \mathrm{~mm} \text { までは } 0.11 \mathrm{kN} / \mathrm{mm})\end{array}$ \\
\hline $\begin{array}{l}\text { 裏込注入 } \\
\text { 軟 質 材 }\end{array}$ & 板ゴム & 压縮弾性係数 $\mathrm{Eg}=3.0 \mathrm{MPa}$ \\
\hline $\begin{array}{l}\text { 裹込注入 } \\
\text { 硬 質 材 }\end{array}$ & エポキシ樹脂 & 圧樎弾性係数 $\quad \mathrm{Er}=890 \mathrm{MPa}$ \\
\hline 銅板接着工 & ブリキ板 & $\begin{array}{lrl}\text { 板 } & \text { 厚 } & \mathrm{t}=0.3 \mathrm{~mm} \\
\text { 引張弹性係数 } & \mathrm{Es}=2.0 \times 10^{5} \mathrm{MPa}\end{array}$ \\
\hline $\begin{array}{l}\text { 炭素織維 } \\
\text { 点 } \\
\text { 補 } \\
\text { 強 }\end{array}$ & 炭素絾維シート & $\begin{array}{ll}\text { 炭素綫維量 } & \text { F.A. F }=50 \mathrm{~g} / \mathrm{m}^{2} \\
\text { 引張弾性係数 } & \text { E ca }=4.1 \times 10^{4} \mathrm{MPa}\end{array}$ \\
\hline
\end{tabular}

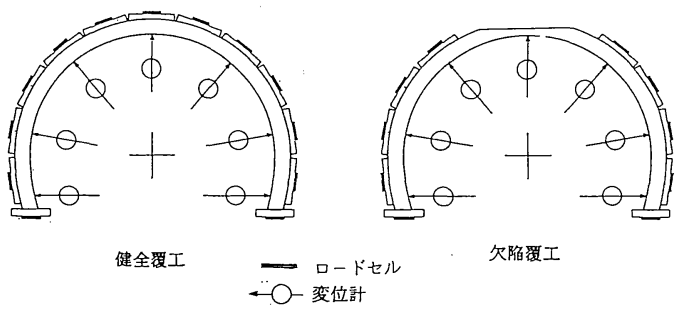

※欠宿爱工に裹込注入を施工するケースは，施工後は健全覆工の配掼。

図一2 計測位置

る硬質円筒形ゴムを用いた，裏込注入工には軟質材とし て板ゴム，硬質材としてエポキシ樹脂を用い，鋼板接着 工にはブリキ板 $t=0.3 \mathrm{~mm}$, 炭素繊維シート補強には炭 素繊維量 $50 \mathrm{~g} / \mathrm{m}^{2}$ のシートをそれぞれ使用しエポキシ樹 脂で接着した。また，使用した炭素繊維シートは，2次 元モデルの実験であることを考虑して, 瀻維方向をトン ネル円周方向の 1 方向のみとしている. 使用材料の諸物 性は，表一2に示すとおりである.

供試体は，図一1 の装置断面図に示す寸法で作製した。 覆工の欠陥については, 天端巻厚 (基本巻厚 $t=20 \mathrm{~mm}$ ) が $t=10 \mathrm{~mm}, t=15 \mathrm{~mm}$ の供試体を作製した. 背面空洞 は円筒形ゴムの地盤ばね材をセットせずに反力が発生し ない状態にすることにより表現した。

c) 計測項目

計測は，載荷重および反力を小型ロードセルにて，法 線方向の覆工内面変位量を棒状型変位計により図一2に 示す位置について夷施し, 目視観察により覆工変状の発 生を随時記録した。また，ひび割れ発生の判定に利用す るために, 覆工内面の周方向にひずみケージを貼付し計， 測した。

d）実験手順

実験の手順は，図一3に示すとおりである，実験装置 に供試体をセットし, 計測機器を配置し実験を行った。 




載荷は載荷板押込み量 $\delta=0.02 \mathrm{~mm} こ ゙ と の$ 変位制御の段 階載荷とし，載荷終了条件である，(1)覆工の終局的破壊， (2)載荷用ボルトのストローク限界, (3)装置の耐荷限界, のいずれかを満たすまで継続し, 載荷中はひび割れの発 生・進展を随時観察記録し, 各荷重段階ごとに載荷重, 反力, 覆工内面変位量, 覆工内面ひずみを計測した.

変状対策工の施工については, 供試体を無対策の状態 で載荷し，ひび割れなどの変状が発生したら載荷を一時 中断し，その状態を保持したまま対策工を施して載荷を 再開した。

e) 相似則

構造物の変形, 変位, 応力について実験する場合は, 弾性範囲内で構造物の幾何学的相似（縮尺 $\boldsymbol{\alpha}$ ) を満足さ せると, 同一荷重強度に対して変形および変位は $1: \alpha$, 応力は $1: 1$ に対応する ${ }^{3 !}$.

本実験においては，ひび割れが発生するまでの弾性的 に挙動すると想定される範囲については相似則が適用で きる.しかしながら,ひび割れ発生後はひび割れの挙動 が変形および変位に大きな影響を与えるため相似則が大 きく変化する．このため, 実験範囲内での比較検討は行 うことはできるが，実験結果から実現象を評価する場合 には，十分な注意が必要である。

\section{(3) 実験結果}

実験終了時の供試体変形状況例を, 写真一 1 写真一 3 に示す.

実験結果については，ケースごとに覆工のひび割れの



写真一1 載荷終了時の供試体変形状況（ケース 3 )

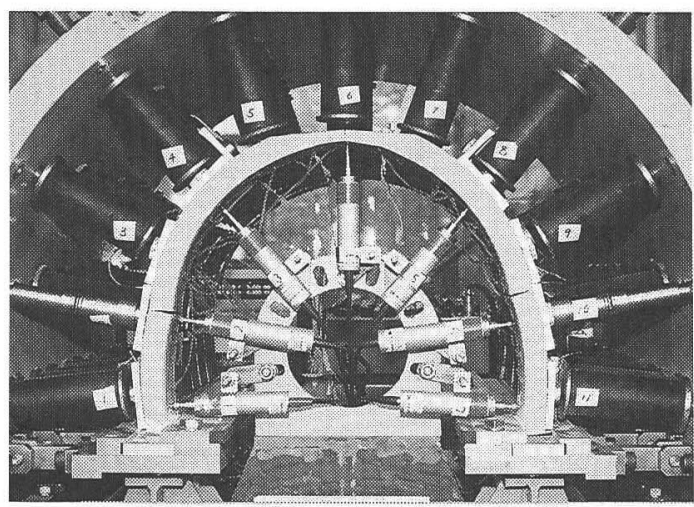

写真一2 載荷終了時の供試体変形状況（ケース 5)

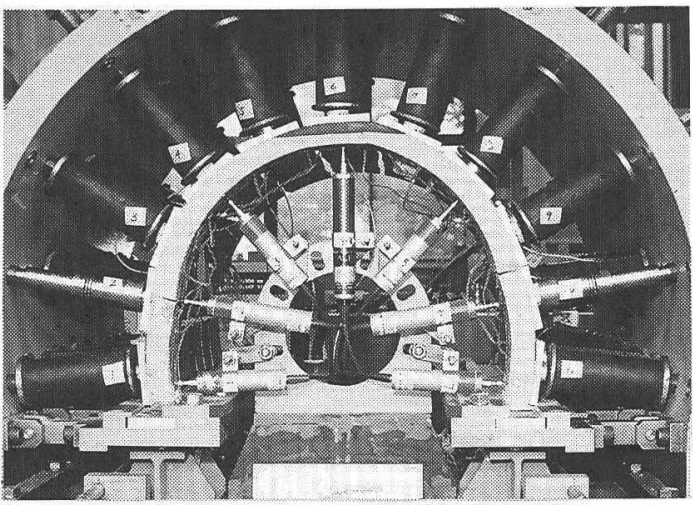

写真-3 載荷終了時の供試体変形状況（ケース 8)

進展過程, 載荷位置の覆工内面の法線方向変位量 $u$ と 荷重 $P$ ，および荷重 $P$ を載荷板断面積 $A$ で除した圧力 $p$ の関係について整理し, 表一3に示す着目パラメータ ごとにまとめ，検討を行った（図一4〜図一7). 図中の 記号の意味は，表一4に示すとおりである。

a) 全体的な変形挙動の傾向

初期ひび割れ発生までは覆工は弾性的な挙動を示し, 
表一3 実験での着目パラメータ

\begin{tabular}{|c|c|c|}
\hline 着目点 & 実験パラメータ & 比較ケース \\
\hline \multirow{2}{*}{ 構造的欠陥の影響 } & 覆工の天端巻厚 & $4(20 \mathrm{~mm}) 、 5(10 \mathrm{~mm}), 6(15 \mathrm{~mm})$ \\
\hline & 背面空洞範团 & $5\left(60^{\circ}\right), 7\left(100^{\circ}\right)$ \\
\hline \multirow{2}{*}{ 対策工の効果 } & 裹込注入工の有無 & 5 (無)、8 (軟質材)、9(硬質材) \\
\hline & 内面補強工の有無 & 1 (無)、2(銅板)、3(炭素㘍維) \\
\hline
\end{tabular}

表一4 実験結果整理記号

\begin{tabular}{|c|c|}
\hline 整理記号 & 容 \\
\hline $0, \Delta, \diamond$ & 引張ひび割れ \\
\hline Q 、 $\Delta, \bullet$ & 圧さ（厌縮ひび割れ） \\
\hline$x$ & 内面補強材の剥離 \\
\hline $1,2,3 \cdots$ & 実験ケース番号 \\
\hline$A, B, C \cdot \cdot$ & 無対策および対策工施工前のひび割れ発生順序 \\
\hline (1)、(2)、(3) -. & 対策工施工後のひび割れ発生順序 \\
\hline $\mathrm{u}$ & 載荷位置での覆工内面の法線方向変位量 $(\mathrm{mm})$ \\
\hline$P$ & 載荷位置での荷重 $(\mathrm{N})$ \\
\hline $\mathrm{p}$ & 載荷位置でのE力（MPa） \\
\hline
\end{tabular}

注） $1 \mathrm{~A} 、 1$ (1)どの最初の 1 は、ケース番号を示している。

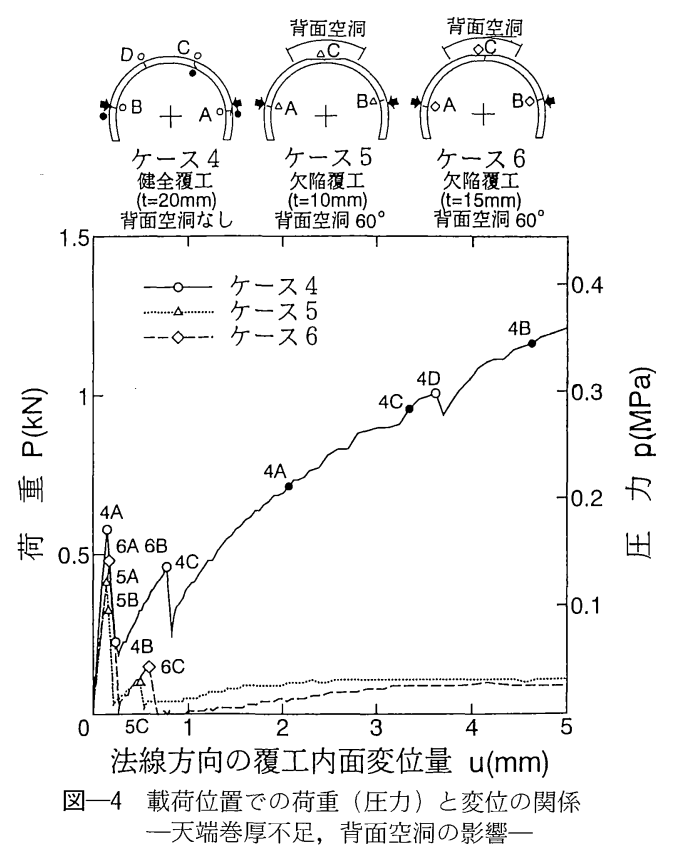

初期ひび割れ発生後は構造系が変化し，新たなひび割れ の発生やひび割れの閉合が見られる.引張ひび割れ，せ ん断ひび割れ，内面補強材の永離が発生すると，載荷位 置で急激な荷重低下および大幅な変位の増加が生じるの で，発生時期を特定することができるが，圧ざの場合は 著しい荷重低下は認められず，発生時期を特定できない 場合があった。

b）構造的欠陥の影響（図一 - 図-5）

覆工耐力に対する構造的欠陥の影響について，横両側

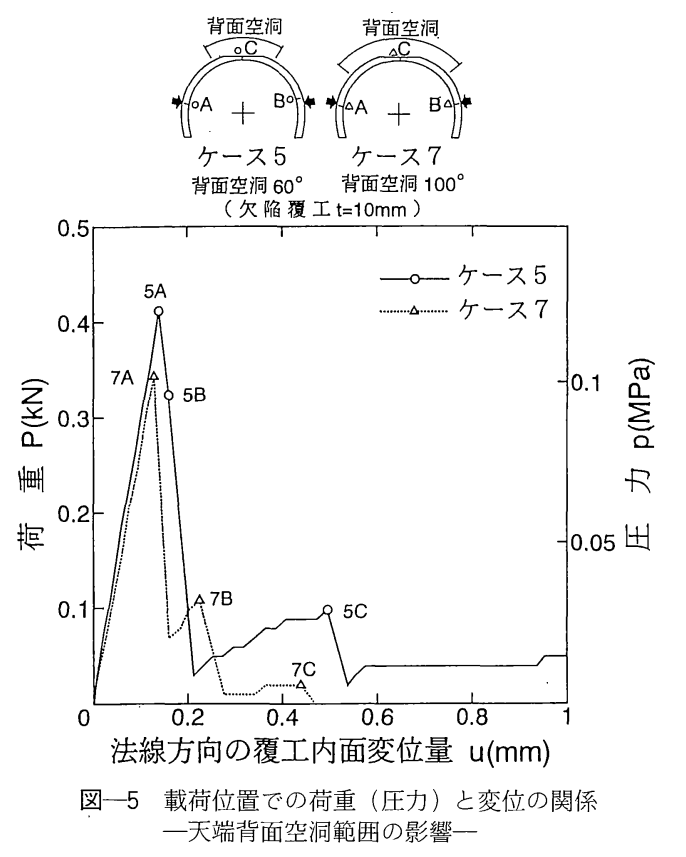

から側壁に載荷した場合のケース 4 ～7 比較する.

図一4に示すように，構造欠陥のない健全な覆工の ケース 4 の場合では，ひび割れの発生に伴い構造系が変 化しながらもア一チ作用により，かなりの変形量まで覆 工耐力を維持している. それに対して, 既設の山岳トン ネルの多くに発生していると考えられる天端覆工巻厚不 足，覆工背面空洞といった構造的欠陥を有するケース 5 ～7 の場合は，脆性的な破壊性状を示し，初期ひび割れ 発生時にピーク荷重が発生し，その後は覆工耐力をほと んど失ってしまった。

覆工天端巻厚不足の影響をケース $5(t=10 \mathrm{~mm})$ とケー ス $6(t=15 \mathrm{~mm})$ により比較すると, 初期ひび割れ発生 までの実験曲線の勾配（覆工の初期の剛性）およびひび 割れ発生後の挙動についてはほとんど差異は見られない が，初期ひび割れ発生荷重に若干の差異が見られ，天端 巻厚不足度合いが，初期ひび割れ発生荷重（覆工耐力） に少なからず影響を与えることが分かる。

次に，覆工背面の空洞範囲の影響について，60範囲 の狭いケース 5 と $100^{\circ}$ 範囲の広いケース 7 にて比較し たのが図一5である．初期ひび割れ発生までの実験曲線 の初期勾配にはほとんど差異は見られないが，初期ひび 割れ発生荷重は空洞範囲が拡大すると若干低下する．大 きな差異があるのは初期ひび割れ発生後の挙動で, どち らの場合も荷重（覆工耐力）は著しく低下するが，空洞 範囲が狭い場合は外力に対して若干の抵抗力を残してい るのに対して，広い場合にはほとんど抵抗なく変形し， 剛性を失っていることがわかる。すすおち, 覆工背面の 空洞範囲が拡大すると地盤反力が期待できず，覆工耐力 


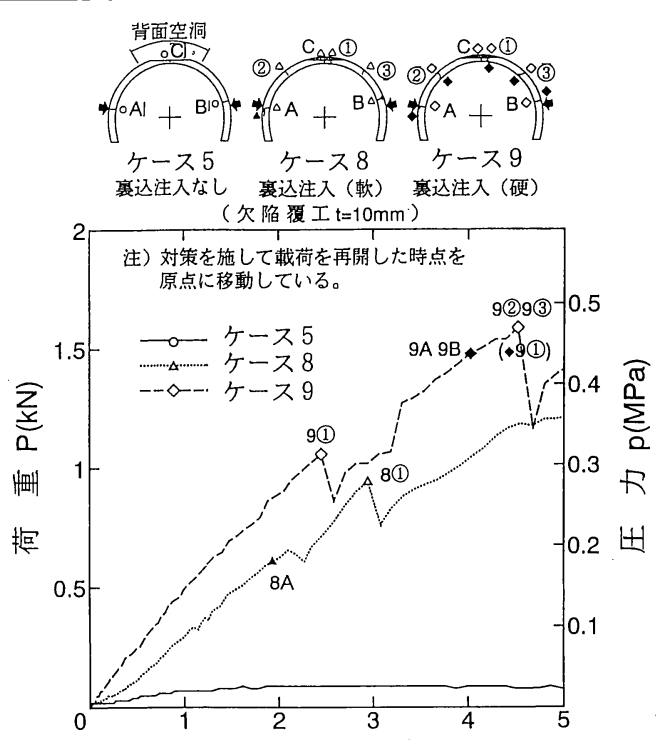

法線方向の覆工内面変位量 $\mathrm{u}(\mathrm{mm})$

図一6 載荷位置での荷重（压力）と変位の関係 一背面空洞への裏込注入工の効果一

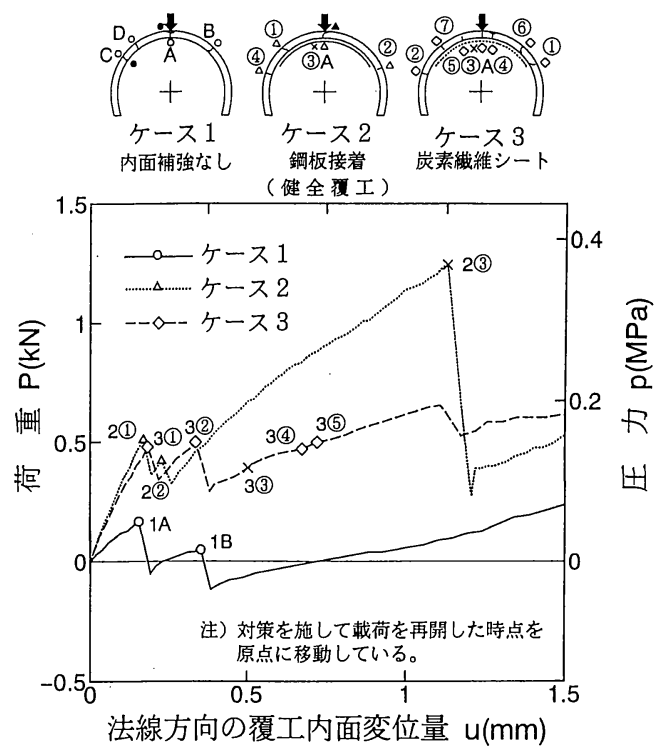

図一7 載荷位置での荷重（圧力）亡変位の関係 一内面補強工の効果一
を維持できないことを示している.

c) 裏込注入工の効果 (図一6)

裏込注入工の効果について, 天端巻厚が不足 $(t=10$ $\mathrm{mm})$ しており $60^{\circ}$ 範囲の背面空洞が存在している供試 体を横両側から側壁に載荷したケースのうち，無対策の 場合のケース 5 , 軟質材 (板ゴム) よる裏込注入工を施 した場合のケース 8 , 硬質材 (エポキシ樹脂) による裏 込注入工を施した場合のケース 9 について比較する。裏 込注入工の施し方としては, 変状が生じているトンネル への対策工をイメージし, 欠陥供試体を無対策の状態で 横両側より載荷し, 載荷位置の覆工内側, 天端覆工外側 に引張ひび割れが発生した後に，あらかじめ空洞の形状 に作製した裏込注入材を設置し，地盤ばね材をセットし て反力が発生するようにして載荷を続行した.なお，図 一6は対策を施して載荷を再開した時点を原点に移動し ている.

図一6から分かるように，裏込注入工を施したケース 8，9は，無対策のケース 5 に比べて，変位が進むにつ れ荷重が大幅に増加している. つまり, 裏込注入工を施 したことにより覆工剛性が大幅に回復し, 覆工耐力が強 化されたことが分かる.

また，裏込注入材の剛性の違いによる効果の差は，材 料剛性が大きいと若干荷重が大きくなり裏込注入工の効 果も大きいと考えられるが，顕著な効果の差があるとは 言えない。これより, 地盤が軟質な場合, 背面空洞への 裏込注入工は覆工耐力の強化に大きな効果を発するが, その効果の程度は注入材料の剛性に大きくは左右されな いことが分かる. d）内面補強工の効果 (図一7)

覆工内面の引張領域に補強材を接着する内面補強工の 効果については, 図一7に示した，構造欠陥のない供試 体を天端から鉛直に載荷したケースで，無対策の場合の ケース 1 , 鋼板接着（ブリキ板 $t=0.3 \mathrm{~mm}$ ）を施した場 合のケース 2 , 炭素繊維シート補強 (繊維量 $50 \mathrm{~g} / \mathrm{m}^{2}$ ) を施した場合のケース 3 について比較する. 内面補強工 の施し方は, 裏込注入工の場合と同様に, 変状が生じて いるトンネルへの対策工をイメージし, 無対策の供試体 を鉛直載荷し, 載荷位置の覆工内側に引張ひび割れが発 生した後に載荷板押込み量 $\delta=0.14 \mathrm{~mm}$ だけ載荷を続行 し, 載荷状態を保持したままで内面補強工を施し，接着 剂硬化のための一定の養生時間が経過した後に載荷を再 開した.なお，図一7 は対策を施して載荷を再開した時 点を原点に移動したものである。

図一7より，内面補強工を施したことにより，無対策 の覆工の耐力を大きく上回る覆工耐力が得られることが 確認できる，また，覆工は内面補強工により変形しにく くなり, 補強材の剛性の高い鋼板接着の方が変形抑制効 果はより大きいことが分かる.つまり, 内面補強工は, その剛性に応じて, 覆工の変状進行抑制に高い効果を期 待できると言える.しかし，ひび割れ進展過程図より分 かるように, 内面補強工の施工箇所端部に応力集中が起 こり，新たな弱点となり得るので注意が必要である.

また，剛性の高い鋼板を接着したケース 2 は，鋼板剥 離による急激な荷重低下が起こり，脆性的な挙動を示し た.これに対して, 鋼板より剛性の低い炭素繊維シート を接着したケース 3 は, 炭素繊維の剝離, 破断が徐々に 




困一8＼cjkstart地盤ばねモデル

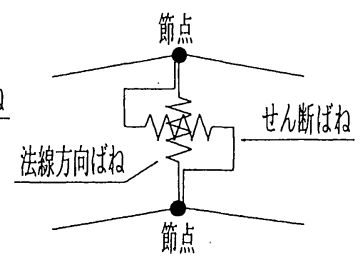

図一9層間ばねモデル

発生するため，急激な荷重低下は発生せず，延性的な破 壊挙動を示した。これより, 過大な剛性の補強材を用い ると変形抑制効果が大きい反面, 急激な破壊挙動を示す ので, 対策工の設計においては, 内面補強工の剛性をい たずらに大きくするのではなく，予想される土圧，許容 できる変位を考慮して，適切な補強材剛性および補強範 囲を決定する必要がある。

\section{3. 数 值 解析}

実験結果のシミュレーションを, 覆工材料, 裏込注入 材料, 内面補強材料などの材料特性は線形弾性とし, 地 盤ばねはバイリニアな材料特性（表一2参照）を考慮し た非線形弾性として, 梁・ば㸚モデルによる 2 次元骨組 解析により行った。 また, そのシミュレーション結果を もとに, 覆工の変形性に与える各種パラメータの感度解 析も行ったので, その結果について述べる.

\section{（1） 骨組解析プログラムの機能}

シミュレーションには, (財)鉄道総合技術研究所所有 の骨組解析プログラム「SAP」t)を使用した．このプロ グラムは, 覆工を多角形の梁材とし, 地盤を節点集中の ばね材（図一8）とした梁・ば㸚モデルを解析すること ができる. 梁材と梁材の結合条件は相対回転角に応じて 曲げモーメントを伝達する回転ばねにて表現できるよう になっており，この機能を用いて覆工のひび割れ発生位 置に回転ばねを配置してモデル化すれば，ひび割れ発生 後の挙動についても解析が可能となる.

さらに，このプログラムは二重巻覆工を別構造系の多 角形の梁材としてモデル化し， 1 次と 2 次の覆工間に働 く力を節点間に作用させた層間ばね（法線方向ばね，お よびせん断ばね; 図一9参照) で表現した二重巻覆工モ デルの解析もできるものとなっている. また, 二層構造 モデルの解析では, 1 次構造系モデルで解析を行い, 解 析途中で 2 次構造系モデルを付加した状態で解析を継続 することができる.この特徴を利用して, 研究目的のひ とつである変状対策工効果を, 裏込注入材や内面補強材 を梁部材としてモデル化して, 覆工との二層構造でシ ミュレートした。

(2) シミュレーション

対策を施さないケースについては, 初期ひび割れ発生 後に別のひび割れが発生するまで，つまり，2 個目のひ

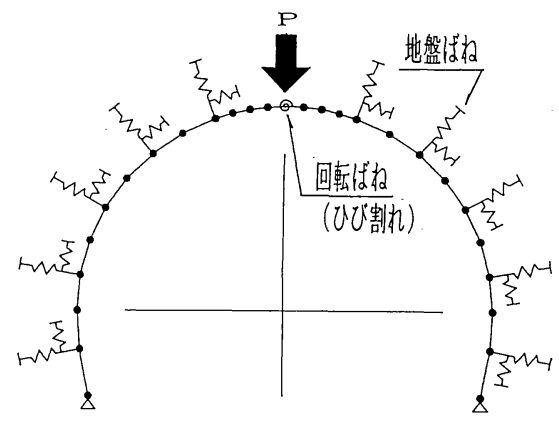

（a）内面補強工施工前

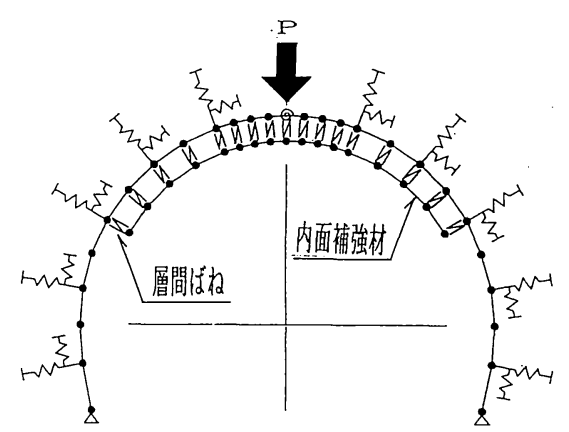

（b）内面補強工施工後

図一10 骨組解析モデル (ケース 2 の場合)

び割れが発生するまで, 裏込注入あるいは内面補強工の 対策を施すケースについては, 初期ひび割れ発生後に対 策工を施してから新たなひび割れが発生するまでについ てシミュレーションを実施した。

a) 解析モデル

図一10に示している例は, ひび割れ発生後に鋼板接 着による内面補強工を施したケース 2 の解析に用いた梁 ば敉モデルである.（a ）は内面補強工施工前の解析モ デルで, 覆工を線形弾性梁材, 地盤ばねを地盤ばね材 (硬 質円筒形ゴム)，の材料特性を考慮した非線形弾性の特性 を有する節点集中の法線方向ばねと法線方向ばねの $1 / 3^{51}$ の接線方向ば㸚で表現し, 載荷位置に発生したひ び割机は弾性回転ばねを配置することでモデル化した。

( b ) は内面補強工施工後の解析モデルで, 内面補強材 (鋼) 板）を線形弾性梁材，内面補強材の接着による拘束力を 層間ばねでモデル化し，（a）の解析モデルに付加した ものである.

b）層間ばねの選定

層間ばねは，基本的には供試体の梁モデル化により決 定した 1 次および 2 次の構造系の節点間の材料の圧縮変 形, せん断変形により算出する. しかしながら, 内面補 強工の場合, 数種類の材料が層を形成しているので, ば ね定数がごの層（材料）に依存するのか, ビの層を合成 すれば良いのかが明確でない. 


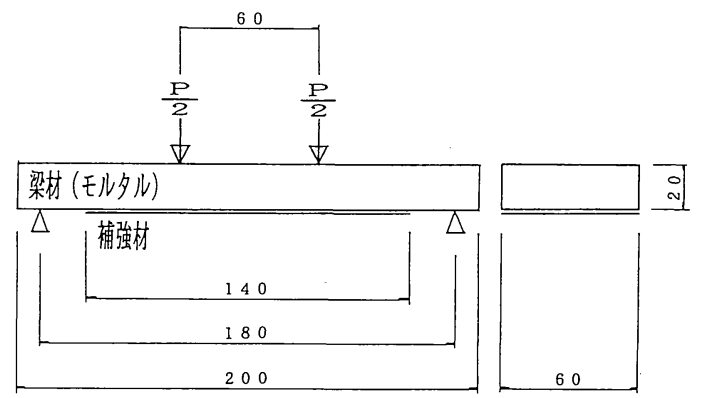

図一11 梁供試体および梁曲げ試験方法

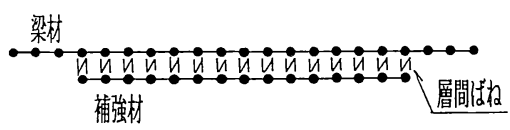

図一12 梁供試体解析モデル

表一5 梁曲げ試験および解析結果

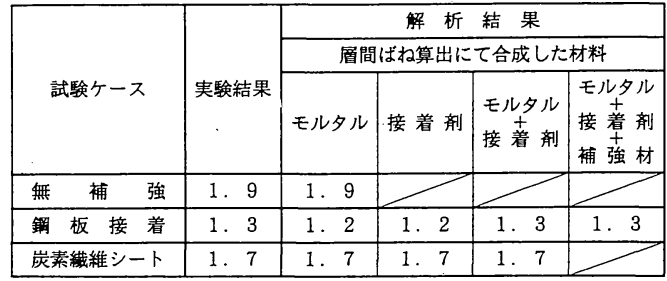

注）表の値は、梁部材スパン中央のたわみ量 uと荷重 P の関係を示す変形性 $\mathrm{u} / \mathrm{P}\left(\times 10^{-4} \mathrm{~mm} / \mathrm{N}\right)$ である。

表に示されるように、首間ばねのばね定数は、 $\mathrm{u} / \mathrm{P}$ 值に対して影響 か小さいことがわかる。

そこで，図一11に示すような，供試体と同寸の断面 を有するセメントモルタル造の梁部材 $(20 \times 60 \times 200$ $\mathrm{mm})$ を作製し，その梁部材に鋼板接着や炭素繊維シー 卜補強を施したものの曲げ試験を行った，また，その梁 部材を図一12に示すように梁・ば㸚モデル化し, 層間 ばね定数を算出するのに合成する材料要素を変化させ て, シミュレーションを実施し, 曲げ試験結果と比較検 討を行った. 結果の整理は, 梁部材スパン中央のたわみ 量 $u$ と荷重 $P$ の関係, すなわち変形性 $(u / P)$ にて行っ た.

試験およびシミュレーションの結果を表一5に示す. 当初, 層間ば称值はセメントモルタル, 接着剂, 補強材 のうちで強度的に弱いと考えられるセメントモルタルに 依存すると考えていたが, SAPによる解析結果は, ば 水定数算出において合成する材料要素を変化させても大 きく変動せず，ぼの場合も実験值とかなり近い值を示し た.これより, ば权定数算出にあたっては，層を形成し ている材料全てを合成して行うこととした，また，内面 補強工の奏験において, 接着剂がセメントモルタルをつ かんだ形で剝離を生じたので, 法線方向ばねの引張限界 （引張限界を超えるとばねが作用しなくなる）をセメン トモルタルの引張強度により決定することとした.


図一13 シミュレーション方法 (ケース 2 の場合)

c）シミュレーションの手順

図一13 は, ケース 2 の実験およびシミュレーション の荷重 $P$ と載荷位置での覆工内面の変位量 $u$ の関係を 示したもので, これを例としてシミュレーション手順の 説明を行う.

初期ひび割れ発生までは弾性回転ばね $K_{R}$ を無限大 (剛結合) として解析する. (解析直線(1))

次に, 初期ひび割れが発生して, 載荷板押込み量 $\delta=$ $0.14 \mathrm{~mm}$ だけ載荷した後の内面補強工を施すために載 荷を中断した時点 S(I) に一致するような弾性回転ばね $K_{R}$ を逆解析により算出する.算出した $K_{R}$ を用いて $\mathrm{S}(\mathrm{I})$ の段階まで解析を実施し（解析直線(2)）， $K_{R}$ はそのまま で内面補強材, 層間ばねを付加し, 対策後の載荷再開時 点 $\mathrm{E}(\mathrm{I})$ から新たなひび割れ発生時点 E(1)までの増加分 の荷重を加えて解析を継続する。(解析直線(3))

図一13 から，解析直線(1)〜 (3)の勾配が実験值を良く シミュレートできていることがわかる，ただし，解析で は, 実験での内面補強工の施工・養生のための時間経過 に伴い発生する応力緩和 $(\mathrm{S}(\mathrm{I})-\mathrm{E}(\mathrm{I}))$ を表現できな いので, S (I) が内面補強工施工後の載荷 (解析) 再開 時点となる.

d）シミュレーション結果

対策工モデルについて，シミュレーションにより得ら 
$\triangle$
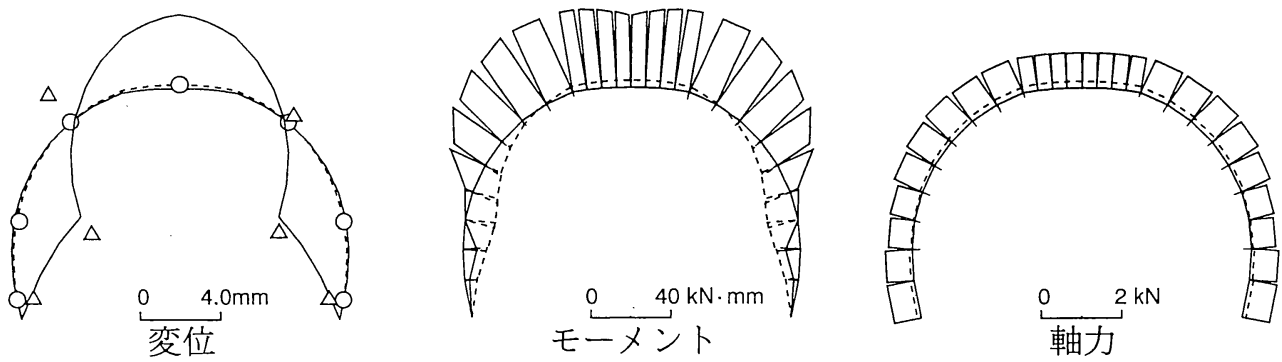

（a）裏込注入工（軟質材）を施したケース 8
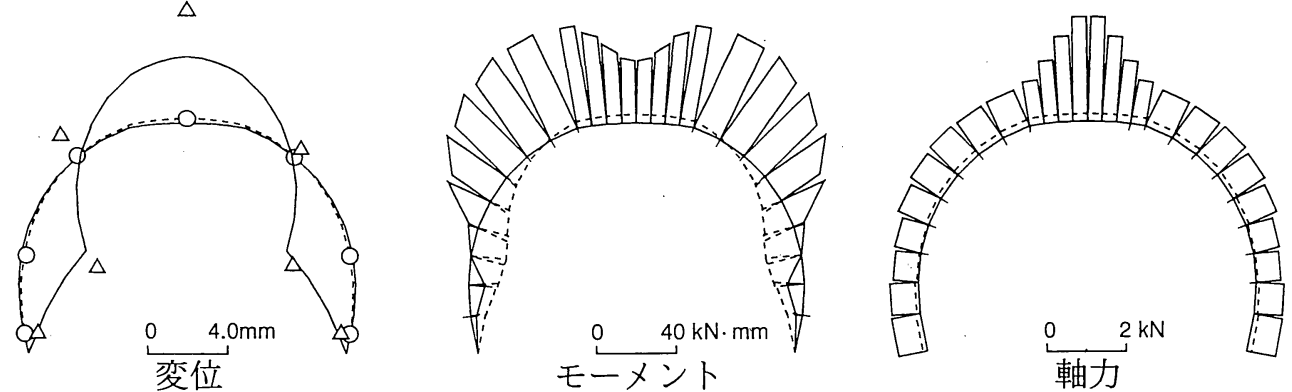

（b）襄込注入工（硬質材）を施したケース 9


（c）内面補強工（鋼板接着）を施したケース 2
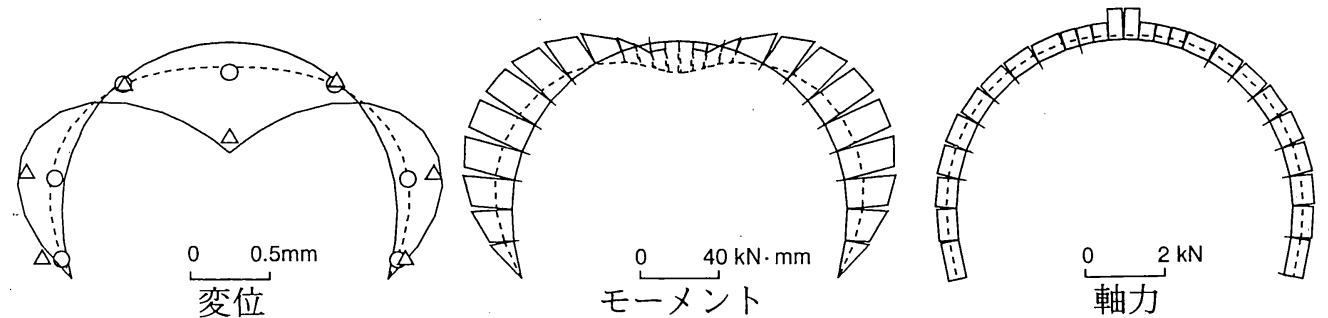

（d）内面補強工（炭素緎維シート）を施したケース 3

\begin{tabular}{|c|c|c|c|c|c|c|}
\hline \multirow{2}{*}{ シミュレートした段階 } & \multicolumn{4}{|c|}{ シミュレーション荷重 $(\mathrm{kN})$} & \multirow{3}{*}{$\begin{array}{l}0 \\
\Delta\end{array}$} & \multirow{4}{*}{$\begin{array}{l}\text { : 奏験での初期ひび割れ発生時の変位量 } \\
\text { : 実験での対策後の最初のひび割れ発生時の変位量 } \\
\text { : 解析での初期ひび割れ発生時の変形状況、断面力 } \\
: \text { 解析での対策後の最初のひび割れ発生時の変形状況、断面力 }\end{array}$} \\
\hline & $4-x 8$ & $5-x 9$ & $4-x 2$ & $4-x 3$ & & \\
\hline 初期ひび割れ発生 時 & 0.34 & 0.41 & 0.41 & 0.50 & & \\
\hline 対策後の新たなひび割れ発生時 & 0.99 & 1.1 & 0.92 & 1.0 & & \\
\hline
\end{tabular}

図一14 シミュレーション結果 



裏込注入材の弾性係数 $E(\mathrm{MPa})$

図一16 パラメー夕感度解析結果 一裏込注入材の剛性の影響—

れた，初期ひび割れ発生時点，対策工施工後に新たにひ び割れが発生した時点の各モードでの覆工変形状況, モーメント, 軸力, および実験における変位量を図一14 に示す.

裏込注入を施工したケースでは天端覆工変位に若干の 差異が見られるが, 全体的には対策工を施した場合の覆 工の変形状況を良くシミュレート出来たと言える.

(3) パラメトリック解析

天端覆工巻厚, 裏込注入材の剛性, 内面補強材の板厚 のそれぞれのパラメータが覆工の変形によ゙のような影響 を与えるかについて感度解析を行い, 弾性的挙動を示す 初期ひび割れ発生まで, あるいは対策工施工後に新たに ひび割れが発生するまでの覆工の変形性 $u / P$ (数値が 大きいと変形しやすく, 小さいと変形しにくいことを示 す）に着目して，結果を整理した．なお，対策前に発生 していると仮定したひび割れはピンにて表現し解析を実



施している.

a) 天端覆工巻厚不足の影響

図一15に示すように，天端覆工巻厚が薄くなると覆 工は変形しやすくなる. また, 図から分かるように, 巻 厚不足割合が $67 \%$ 付近にひとつの変化点があり，これ より不足割合が大きくなると, 変形に対する抵抗力の減 少度合いが少なくなり，一定值に近づく傾向があるのが 特徴的である。

b）裏込注入材の剛性の影響

図一16に示すように，裏込注入材の剛性が大きけれ ば覆工の変形性は小さくなり, 対策効果が向上すること が分かる. しかしながら，ある程度以上は材料剛性を大 きくしても顕著な変形抑制効果の向上は得られないこと が分かる、これは, 覆工模型実験結果から得られた傾向 と一致している.

なお，この感度解析は，実験と同様に，かなり軟質な 地盤を対象亡しているため, 地盤の剛性が大きい場合に ついては，別途検討が必要である.

c）内面補強材厚の影響

図一17に示すように, 内面補強材厚を厚くすれば, 覆工変形の抑制効果は大きくなる. 鋼板の場合は, 材料 自体の剛性が大きいため, 板厚が比較的薄い範囲では, 対策を施すことによる変形抑制効果は板厚増加に伴い顕 著に大きくなるが， $t=0.2 \mathrm{~mm}$ 程度を境にして，板厚を 厚くしても効果は顕著には大きくならない。これに対し て，炭素繊維シートは，鋼板に対して岡性が比較的小さ いので, 補強量 (積層シート枚数) 増加に伴い, 変形抑 制効果がほぼ比例関係で増加していく傾向がある.

\section{4. 結 論}

トンネル覆工の構造的欠陥がその変形挙動特性に与え る影響, および変状対策工の効果の把握を目的として, 
模型実験および解析を行った結果，いくつかの知見を得 ることができたので，以下にまとめる.

（1）覆工模型実験装置を用いた実験結果の比較によ り, 覆工の構造的欠陥（天端巻厚不足, 背面空洞) が, 覆工剛性および耐力の低下に顕著に関与していること, 変状対策としての裏込注入工や内面補強工は十分な効果 を発揮することが確認できた。

（2）天端が巻厚不足で背面空洞が存在すると, 天端 の地盤反力が得られないので, 側圧に対する覆工の剛性, 耐力を著しく低下させ，初期ひび割れが発生した後は， ほとんど岡性を失ってしまう。また，空洞範囲が大きい と地盤反力がより期待できなくなるので，耐力の低下へ とつながる.

（３）背面空洞に裏込注入工を施すと, 覆工に地盤反 力を伝達することができ, 覆工の剛性, 耐力を回復する ことができる. また, 裏込注入工の効果は, 注入材の岡 性にはあまり依存しないことが，奏験結果およびパラ メー夕感度解析結果より確認できた。これより，軟質な 地盤においては, 地盤反力をある程度伝達できる材料で あれば，裏込注入工の効果を十分発揮することを示唆し ていると言える.

（4）曲げ弓張作用により変状が起こした覆工に内面 補強を施すと, 変形の抑制効果が大きく, 大幅な岡性の 回復, または健全覆工を上回る耐力を得ることが確認で きた。ただし, 内面補強工施工箇所の端部に応力が集中 し, 新たな弱点となる場合があるので注意が必要である.

（５）今回の実験では, 鋼板接着の場合は使用した材 料の剛性 (補強量) が大きく, 覆工の変形抑制効果が過 剰であったので，脆性的な破壊形態を示した。これに対 して, 剛性の小さい炭素繊維シート補強の場合は, 急激 な破壊形態を示さず，延性的な破壊形態を示した。また， パラメー夕感度解析からは, 剛性が小さい(板厚が薄い)
場合は変形抑制効果の改善度合いがある程度比例的に現 れるが，ある一定の補強量を越えると変形抑制効果の改 善が顕著に現れなくなる傾向が把握できた.

（6）（5）の知見から, 内面補強工を施す場合は, 材料剛性をいたずらに大きくするのではなく,予想土圧, 許容変位を考慮した適切な剛性および接着範囲を設計す ることが必要である。

今後も, 覆工の構造欠陥および対策工に関する実験お よび解析を継続し，最終目的である健全度評価法の確立 と変状対策工の設計基準の作成を達成したいと考えてい る.

謝辞：最後に，実験の実施にご協力いただいた（株）ダ イヤコンサルタント東京支店の川上義輝氏，炭素繊維 シート補強の実験にご協力をいただいた（株)東燃総合 研究所の斉藤誠氏, 田中良典氏に深甚なる謝意を表しま す.

参 考 文 献

1）朝倉俊弘・小島芳之・安東豊弘：トンネル覆工の力学挙 動解析一複線トンネル覆工模型実験のシミュレーション 一, トンネル工学研究発表会論文・報告集第 1 巻, pp. 183 188, 1991.

2）朝倉俊弘 - 小島芳之. 安東豊弘 - 佐藤 豊 - 松浦章夫： トンネル覆工の力学挙動に関する基礎的研究, 土木学会 論文集, No.493/III-27, pp. 79〜88； 1994.

3）江守一郎・D. J. シューリング：模型実験の理論と応用, 技報堂, 1973 .

4）半谷哲夫：二次覆工を有するシールドトンネル覆工の力 学的特性に関する研究, 鉄道技術研究報告, No. 1303, 1985.

5）日本国有鉄道：建造物設計標準解説一基礎構造物，抗土 圧構造物一，1986。

(1993.6.14 受付)

\section{BEHAVIOR OF STRUCTURALLY DEFECTIVE TUNNEL LINING AND EFFECTIVE- NESS OF INNER REINFORCEMENT}

Toshihiro ASAKURA, Toyohiro ANDO, Fujio OMATA, Kazuyuki WAKANA and Akio MATSUURA

Most of existing tunnels have structural defects, such as lack of the thickness in the crown and presence of an opening behind the lining on account of its construction. We have carried out a model test and a frame analysis of influence of the defects on the lining behavior and effects of the inner reinforcement and backfill grouting on the tunnel lining. 